Jurnal Agro 7(2), 2020

\title{
KOMPONEN EPIDEMI PENYAKIT ANTRAKNOSA PADA TANAMAN CABAI DI KECAMATAN BATURRADEN KABUPATEN BANYUMAS
}

\section{EPIDEMIC COMPONENTS OF CHILLI ANTHRACNOSE AT BATURRADEN DISTRICT BANYUMAS REGENCY}

\author{
Nur Prihatiningsih ${ }^{*}$, Heru Adi Djatmiko, Erminawati \\ Fakultas Pertanian Universitas Jenderal Soedirman \\ Jl.dr Soeparno No 61 Purwokerto 53123 \\ *Korespondensi : prihatiningsihnur@gmail.com
}

Diterima: 13 Maret 2020 / Disetujui : 28 November 2020

\begin{abstract}
ABSTRAK
Penyakit antraknosa merupakan penyakit utama pada tanaman cabai yang dapat menyebabkan kegagalan panen dan kerugian mencapai $80 \%$. Tujuan penelitian untuk menilai perkembangan penyakit antraknosa cabai di Kecamatan Baturraden, menguji pengaruh komponen epideminya terhadap pertumbuhan jamur Colletotrichum gloeosporioides dan penekanan penyakit pada buah cabai. Metode penelitian yang digunakan adalah survey dengan pengambilan sampel secara purposive random sampling di empat desa di Kecamatan Baturraden Kabupaten Banyumas. Pengujian pengaruh komponen epidemi dilakukan di Laboratorium Perlindungan Tanaman Faperta Unsoed dengan menumbuhkan jamur $C$. gloeosporioides pada beberapa suhu dan menguji penekanan penyakit pada buah cabai. Rancangan yang digunakan adalah Rancangan Acak Lengkap. Variabel pengamatan yaitu intensitas penyakit, laju infeksi, kecepatan pertumbuhan jamur, persentase penghambatan pertumbuhan jamur dan penekanan penyakit pada buah cabai. Hasil penelitian menunjukkan bahwa penyakit antraknosa di desa Kemutug Lor menunjukkan intensitas penyakit tertinggi yaitu $76 \%$ dengan laju infeksi 0,345 unit/hari. Suhu optimum yang mendukung pertumbuhan C. gloeosporioides yaitu $29^{\circ} \mathrm{C}$, dengan kecepatan pertumbuhan $14,72 \mathrm{~mm}$ hari ${ }^{-1}$. Pertumbuhan C. gloeosporioides dihambat oleh bakteri end ofit cabai BE2 sebesar 78,6\%. Bakteri endofit cabai dapat menekan penyakit antraknosa pada buah cabai dengan efektivitas 30,93\%.
\end{abstract}

Kata kunci: antraknosa, cabai, epidemi, penilaian penyakit

\begin{abstract}
Anthracnose is the main disease in chili that can cause crop failure and losses up to $80 \%$. The aim of the study was to assess the development of chili anthracnose in the Baturraden district, to examine the effect of its epidemic components on the growth of Colletotrichum gloeosporioides, and suppression of anthracnose. The research method used was a survey with purposive random sampling in four villages in Baturraden district, Banyumas Regency. Testing the effect of epidemic components was carried out in Plant Protection Laboratory, Faculty of Agriculture Unsoed by growing the C. gloeosporioides at several temperatures, and testing the disease suppression of chilies with chili endophytic bacteria. The design used was a Completely Randomized Design. The variables observed were disease intensity, infection rate, fungal growth
\end{abstract}

Cite this as: Prihatiningsih, N., Djatmiko, H. A. \& Erminawati. (2020). Komponen epidemi penyakit antraknosa pada tanaman cabai di kecamatan baturaden kabupaten Banyumas. Jurnal Agro, 7(2), 203-212. https://doi.org/10.15575/8000 
rate, percentage of inhibition of fungal growth, and disease suppression in chilies. The results showed that chili anthracnose in the village of Kemutug Lor showed the highest intensity of $76 \%$ with an infection rate of 0,345 units per day. The optimum temperature that supported the growth of C. gloeosporioides was $290 \mathrm{C}$ with a growth rate of $14,72 \mathrm{~mm}$ day-1. Growth of C. gloeosporioides was inhibited by endophytic bacteria BE2 chili by $78,6 \%$. Chili endophytic bacteria could suppress anthracnose in chilies by $30,93 \%$ effectivity.

Keywords: anthracnose, chili, epidemic, disease assessment

\section{PENDAHULUAN}

Cabai (Capsicum spp.) merupakan tanaman hortikultura yang penting dan diprioritaskan pengembangannya sesuai dengan permintaan yang semakin meningkat. Manfaat cabai selain sebagai penyedap bumbu masakan yang mempunyai rasa pedas, juga sebagai tanaman hias, dan bahan obat-obatan. Produksi cabai di Indonesia masih di bawah Cina, Taiwan dan Mexico yang hasilnya mencapai $3 \mathrm{t} \mathrm{ha}$. Keberlanjutan produksi cabai terganggu adanya faktor biotik seperti adanya serangga dan patogen (Prasad, 2016). Penyakit antraknosa merupakan penyakit utama pada cabai baik di daerah tropis maupun subtropis, yang disebabkan oleh jamur Colletotrichum spp. Di Indonesia sering ditemukan C. capsici, C. gloeosporioides dan C. accutatum, meskipun masih terdapat Colletotrichum yang lain yaitu $C$. dematium, C. coccodes. Colletotrichum yang menginfeksi tanaman cabai dibedakan berdasarkan stadium pertumbuhan tanaman. Daun dan batang cabai terinfeksi oleh $C$. coccodes dan $C$. dematium, sedangkan $C$ acutatum dan $C$. gloeosporioides menginfeksi buah (Sangdee et al., 2011; Welideniya et al., 2019). C. capsici ditemukan menyebabkan infeksi pada cabai merah dan C. gloeosporioides menginfeksi baik pada buah muda maupun buah cabai yang matang, sehingga menyebabkan kehilangan hasil sampai $100 \%$ (Jayawardana et al., 2015).

Penyakit antraknosa disebut juga dengan penyakit pathek (Herwidyarti et al., 2013). Kerugian hasil karena penyakit antraknosa dapat mencapai $80 \%$ apabila kondisi mendukung untuk perkembangan patogen (Than et al., 2008). Konidium Colletotrichum dapat terpencar oleh angin sehingga penularannya sangat cepat bahkan dapat merata pada lahan cabai. Serangan patogen Colletotrichum dapat terjadi pada tanaman cabai fase vegetatif sampai menjelang panen (Machenahalli et al., 2014; Saxena et al., 2016). Selain buah yang diserang, patogen ini juga dapat menginfeksi batang, ranting, daun, dan buah. Beberapa tanaman yang dapat terserang oleh jamur Colletotrichum adalah cabai, bawang merah, tomat, terung, melon, semangka, mentimun, pepaya dan sebagainya. Infeksi $C$. capsici banyak terjadi pada musim hujan dan lahan yang berdrainase kurang baik.

Gejala awal serangan ditandai dengan adanya bintik-bintik kecil yang berwarna kehitam-hitaman dan sedikit melekuk (sunken). Selanjutnya buah yang terinfeksi mengerut, membusuk dan rontok/gugur. Bercak berbentuk bundar cekung dengan berbagai ukuran dan berkembang pada buah muda. Pada serangan parah, bercak akan bersatu dan merata hampir di seluruh permukaan kulit buah (Than et al., 2008). Massa spora jamur berwarna merah jambu ke orange terbentuk dalam cincin yang 
konsentris pada permukaan bercak. Bercak yang sudah menua, aservulus akan kelihatan. Dengan rabaan, akan terasa titiktitik hitam kecil, di bawah mikroskop akan tampak rambut-rambut halus berwarna hitam. Perkembangan penyakit secara epidemik dicirikan dengan spora yang terbentuk cepat dan berlebihan, memencar secara cepat pada permukaan buah Bercak dapat menjalar ke tangkai buah dan meninggalkan bintik yang tidak beraturan berwarna merah tua dengan tepinya berwarna merah tua gelap (Than et al., 2008; Damm et al., 2009; Welideniya et al., 2019).

Daur hidup jamur C. capsici diawali dari pertumbuhan koloni berupa miselium berwarna putih, dengan pertumbuhan miselium aerial di permukaan. Secara perlahan-lahan berubah menjadi hitam dan akhirnya membentuk aservulus, yang tertutup warna merah muda sampai cokelat muda yang merupakan masa konidium. Miselium terdiri atas beberapa septa, inter dan intraseluler hifa. Aservulus dan stroma pada batang berbentuk hemispirakel dan ukuran 70-120 $\mu \mathrm{m}$. Seta menyebar, berwarna coklat gelap sampai coklat muda. Seta terdiri atas beberapa septa dan ukuran +150 $\mu \mathrm{m}$. Konidium berbentuk hialin, uniseluler, berukuran 17-18 x 3-4 $\mu \mathrm{m}$. Konidium dapat berkecambah pada permukaan buah yang hijau atau merah tua. Tabung kecambah akan segera membentuk apresorium sebagai bantalan infeksi ketika jamur akan melakukan penetrasi ke jaringan tanaman inang (Saxena et al., 2016).

Faktor yang mempengaruhi penyakit dapat dilihat dari komponen epidemi adalah dari tiga faktor utama yaitu patogen, inang dan lingkungan. Jamur membentuk badan buah aservulus dalam lingkaran-lingkaran terpusat, yang membentuk konidium berwarna merah jambu. Jamur bereproduksi dengan membentuk masa konidium dalam aservulus yang tersusun di bawah epidermis tanaman inang (Kommula et al., 2017). Konidium keluar berupa butiran berwarna putih, kuning, jingga, hitam dan warna lain sesuai dengan pigmen yang dikandung. Miselium berwarna putih hingga abu-abu. Warna koloni oranye hingga merah muda pada medium biakan. Suhu optimum $27^{\circ} \mathrm{C}$ dan kelembapan udara 80\% merupakan kondisi optimum untuk perkembangan penyakit antraknosa cabai (Than et al., 2008; Kommula et al., 2017). Perkembangan penyakit antraknosa pada skala penelitian sebelumnya menunjukkan laju infeksi sebesar 0,092 unit hari ${ }^{-1}$ (Wulansari et al., 2017). Nilai laju infeksi belum ada presisi yang tepat, (van der Plank, 1963) menyebutkan untuk gejala hawar (blight) nilai laju infeksi berkisar 0,23-0,46 unit hari-1.

\section{BAHAN DAN METODE}

Bahan penelitian ini adalah tanaman cabai di empat Desa di Kecamatan Baturraden Kabupaten Banyumas. Penelitian dilaksanakan pada bulan April-Juli 2018. Metode penelitian dilakukan secara survey untuk pengamatan intensitas penyakit dan secara eksperimen untuk mengamati pengaruh komponen epidemi terhadap jamur C. gloeosporioides sebagai penyebab penyakit antraknosa di empat desa tersebut, dengan Rancangan Acak Lengkap.

\section{Penilaian penyakit antraknosa}

Penelitian dilaksanakan secara survey di empat desa di Kecamatan Baturaden yaitu desa Kemutug Lor, Kemutug Kidul, Karang Tengah dan Rempoah. Pengambilan sampel dilaksanakan secara purposive random 
sampling. Setiap desa diambil lokasi yang mewakili dengan kriteria umur tanaman, varietas cabai yang ditanam, musim tanam, dan luas lahan. Berdasarkan kriteria tersebut adalah umur tanaman \pm 50 hari setelah tanam (hst), varietas cabai merah yang digunakan adalah varietas lokal Baturraden yang ditanam pada bulan MaretApril (akhir musim hujan) dengan luas lahan $\pm 500 \mathrm{~m}^{2}$. Penilaian penyakit tanaman diawali dengan melihat gejala antraknosa yang dilakukan selama lima kali pengamatan dengan interval pengamatan 10 hari, kemudian menilai intensitas penyakit menggunakan rumus yang dikemukakan oleh (Prasad, 2016; Mishra et al., 2018), sebagai berikut:

$$
\mathrm{IP}=\frac{\mathrm{a}}{\mathrm{b}}
$$

$\mathrm{IP}=$ indeks penyakit = PDI: percent disease index, a: jumlah buah cabai terinfeksi pada tanaman sampel, b: jumlah buah tiap tanaman.

Variabel laju perkembangan penyakit antraknosa di keempat desa sampel dihitung berdasarkan rumus (van der Plank, 1963) : $\mathrm{X}_{\mathrm{t}}$ $=X_{0} . e^{r t}$ dengan nilai $r$ (laju infeksi) dihitung menggunakan rumus bunga majemuk karena patogennya tular-udara dan dapat tersebar cepat.

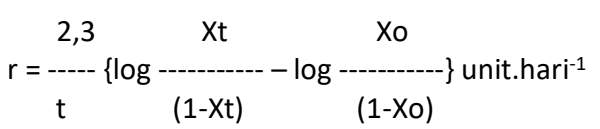

\section{Pengaruh Suhu sebagai Komponen Epidemi terhadap Pertumbuhan Penyebab Penyakit Antraknosa (C. gloeosporioides)}

C. gloeosporioides diperoleh dari daerah yang diamati yaitu Kemutug Lor, Kemutug Kidul, Karang Tengah dan Rempoah, kemudian diidentifikasi secara morfologi menunjukkan hasil yang sama berdasarkan warna koloni putih dengan warna bagian bawah pada cawan Petri hitam dan konidium yang berbentuk batang lurus menunjukkan C. gloeosporioides. (Oo \& Oh, 2016). Salah satu komponen epidemi penyakit yaitu faktor lingkungan seperti suhu. Suhu berpengaruh terhadap pertumbuhan jamur patogen. C. gloeosporioides yang diperoleh dari hasil isolasi ditumbuhkan pada medium PDA dengan berbagai suhu untuk mengetahui pengaruh suhu terhadap pertumbuhan jamur C. gloeosporioides. Pertumbuhan koloni jamur C.gloeosporioides diamati pada beberapa suhu yaitu 15, 25, 29 (suhu kamar) dan $35^{\circ} \mathrm{C}$ di laboratorium. Suhu $15^{\circ} \mathrm{C}$ di dalam kulkas, $25^{\circ} \mathrm{C}$ di dalam ruang ukuran $3 \times 3 \mathrm{~m}^{2}$ berAC suhu $25^{\circ} \mathrm{C}, 29^{\circ} \mathrm{C}$ dalam ruangan, dan $35^{\circ} \mathrm{C}$ di dalam inkubator bersuhu $35^{\circ} \mathrm{C}$. Miselium dari koloni jamur C. gloeosporioides berumur 6 hari dipotong dengan bor gabus berdiameter $5 \mathrm{~mm}$ ditanam pada medium PDA di tengah cawan Petri berdiameter 9 $\mathrm{cm}$, kemudian diinkubasi pada suhu 15, 25, 29 dan $35^{\circ} \mathrm{C}$. Variabel pengamatan yaitu diameter koloni yang diukur setiap hari untuk mengetahui kecepatan pertumbuhan pada variasi suhu dengan satuan mm hari ${ }^{-1}$.

\section{Pengendalian penyakit melalui pendekatan epidemi}

Kajian pengendalian penyakit antraknosa melalui pendekatan epidemi dilakukan dengan tujuan untuk menekan laju infeksi (r). Pengendalian penyakit melalui kajian penekanan pertumbuhan patogen dan penekanan perkembangan gejala dilakukan di laboratorium bertujuan untuk menekan laju pertumbuhan jamur patogen $C$. gloeosporioides ditumbuhan secara dual culture berhadapan dengan bakteri endofit 
cabai secara in vitro dan pada buah cabai. Perlakuan pada cabai dengan cara bakteri endofit dioleskan pada permukaan buah cabai yang akan diinokulasi dengan $C$. gloeosporioides. Variabel pengamatan adalah pada uji in vitro adalah zona hambatan dan pada buah cabai adalah luas bercak yang diukur dengan menggunakan milimeter blok dari plastik transparan.

Data yang diperoleh secara in vitro dianalisis dengan uji $F$ dan apabila berpengaruh nyata dilanjutkan dengan BNT taraf kesalahan $5 \%$.

\section{HASIL DAN PEMBAHASAN}

\section{Penilaian penyakit antraknosa}

Pengamatan Intensitas penyakit antraknosa di empat desa di Kecamatan Baturraden ditunjukkan pada Tabel 1. Desa Kemutug Lor mempunyai ketinggian tempat $350 \mathrm{~m}$ dpl menunjukkan intensitas penyakit antraknosa tertinggi (76\%) dengan laju infeksi 0,345 unit.hari ${ }^{-1}$.

Tabel 1. Intensitas penyakit antraknosa dan laju infeksi pada empat desa

\begin{tabular}{lcc}
\hline Nama Desa & Intensitas Penyakit (\%) & Laju infeksi $(r)$ unit hari $^{-1}$ \\
\hline Kemutug Lor & $76,00 \mathrm{a}$ & 0,345 \\
Kemutug Kidul & $63,44 \mathrm{~b}$ & 0,115 \\
Karang Tengah & $66,32 \mathrm{~b}$ & 0,123 \\
Rempoah & $66,70 \mathrm{~b}$ & 0,127 \\
\hline
\end{tabular}

Keterangan: Angka yang diikuti oleh huruf yang sama pada kolom yang sama menunjukkan tidak berbeda nyata pada uji lanjut BNT $5 \%$

Desa Kemutug Lor merupakan desa dengan ketinggian tempat tertinggi dibanding tiga desa lainnya. Pada saat penelitian tanaman cabai di Desa Kemutug Lor menunjukkan intensitas tertinggi karena didukung oleh kondisi lingkungan seperti pertanaman di sekitarnya adalah cabai dengan umur yang lebih tua, sehingga memperparah penyakit karena terjadi perpindahan inokulum. Tiga desa lainnya terdapat tanaman cabai juga di sekitarnya dengan umur yang hampir sama dan tanaman lain seperti jagung, padi, sehingga dapat mengurangi penyebaran patogen. Apabila dibandingkan dengan laju infeksi penyakit blight menurut (van der Plank, 1963) untuk gejala hawar (blight) nilai laju infeksi berkisar 0,23-0,46 unit hari ${ }^{-1}$, maka laju infeksi penyakit antraknosa masih dalam kisaran laju infeksi penyakit hawar (blight), sehingga dapat dikatakan laju perkembangan penyakit antraknosa menyerupai laju perkembangan penyakit hawar, yaitu termasuk gejala nekrosis yang cepat meluas.

Perkembangan penyakit antraknosa di empat desa dapat dilihat pada Gambar 1, yang menunjukkan bahwa perkembangan penyakit antraknosa selama pengamatan, tercepat adalah di desa Kemutug Lor dengan laju infeksi 0,345 unit hari ${ }^{-1}$. Hal ini disebabkan oleh kondisi di sekitar pertanaman cabai di Kemutug Lor lebih rapat jarak petaknya, dan penyakit antraknosa juga terdapat pada petak di sebelahnya yang merupakan sumber inokulum karena tanamannya sudah lebih tua. Hal ini menunjukkan bahwa komponen epidemi yaitu tanaman, patogen dan lingkungan termasuk lingkungan mikro di sekitar petak pertanaman cabai sangat mendukung perkembangan penyakit. 


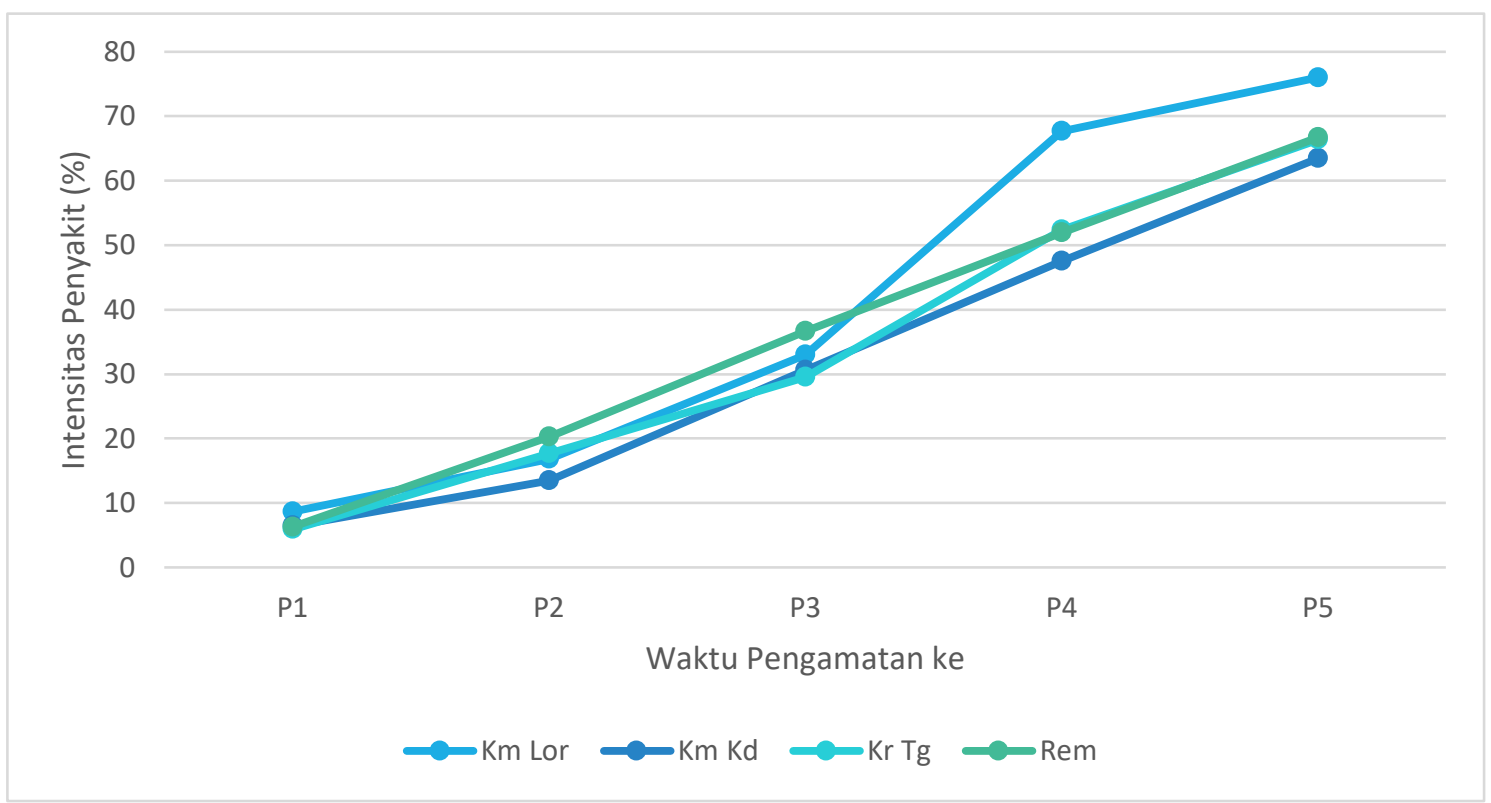

Gambar 1. Perkembangan penyakit antraknosa di empat desa pada Kecamatan Baturraden.

Pertumbuhan C. gloeosporioides pada berbagai suhu inkubasi.

Pertumbuhan koloni $C$. gloeosporioides pada berbagai suhu inkubasi ditunjukkan pada Tabel 2, kecepatan pertumbuhan koloni $C$. gloeosporioides tertinggi pada suhu inkubasi $29^{\circ} \mathrm{C}$ (suhu kamar) yaitu $14,72 \mathrm{~mm}$ hari $^{-1}$. Hasil ini lebih tinggi dibandingkan dengan hasil penelitian dari (Kommula et al., 2017) menunjukkan kecepatan pertumbuhan Colletotrichum capsici adalah $10,2 \mathrm{~mm}$ hari $^{-1}$.

Tabel 2. Pertumbuhan koloni C. gloeosporioides pada berbagai suhu

\begin{tabular}{lr}
$\begin{array}{c}\text { Perlakuan suhu } \\
\left({ }^{\circ} \mathrm{C}\right)\end{array}$ & $\begin{array}{l}\text { Kecepatan pertumbuhan koloni } \\
\left(\mathrm{mm} \mathrm{hari}^{-1}\right)\end{array}$ \\
\hline 15 & 2,24 \\
25 & 13,6 \\
29 (suhu kamar) & 14,72 \\
35 & 1,28 \\
\hline
\end{tabular}

Keterangan: suhu $15^{\circ} \mathrm{C}$ di kulkas, $25^{\circ} \mathrm{C}$ di dalam ruang ukuran $3 \times 3 \mathrm{~m}^{2}$ berAC suhu $25^{\circ} \mathrm{C}, 29^{\circ} \mathrm{C}$ dalam ruangan, dan $35^{\circ} \mathrm{C}$ di dalam inkubator bersuhu $35^{\circ} \mathrm{C}$

Koloni C. gloeosporioides tumbuh cepat pada suhu $25-29^{\circ} \mathrm{C}$, suhu di bawah dan di atas kisaran tersebut terhambat pertumbuhannya. Hal ini sependapat dengan (Saxena et al., 2016) bahwa suhu sekitar $27^{\circ} \mathrm{C}$ dengan kelembapan relatif $80 \%$ merupakan kondisi optimum untuk menetapnya penyakit, sehingga merupakan kisaran suhu yang tepat untuk pertumbuhan patogen, maka akan meningkatkan intensitas penyakit. Selanjutnya untuk perkembangan penyakit tergantung pada kultivar inang sejalan dengan resistensi terhadap patogen. 
Pengendalian penyakit antraknosa melalui pendekatan epidemi

Pendekatan cara pengendalian penyakit dilakukan dengan mempelajari pengaruh lingkungan terhadap pertumbuhan patogen dan perkembangan penyakit. Penekanan pertumbuhan C. gloeosporioides secara in vitro ditunjukkan pada Tabel 3 dan Gambar 2.

Tabel 3. Penghambatan pertumbuhan C. gloeosporioides oleh bakteri endofit cabai

\begin{tabular}{lc}
\hline Bakteri endofit cabai & Penghambatan (\%) \\
\hline K & $0 \mathrm{c}$ \\
BE1 & $67,4 \mathrm{~b}$ \\
BE2 & $78,6 \mathrm{a}$
\end{tabular}

Keterangan: angka yang diikuti oleh huruf yang sama pada kolom yang sama menunjukkan tidak berbeda nyata dengan uji lanjut BNT 5\%. K: kontrol, BE1: bakteri endofit cabai no isolat 1, BE2: bakteri endofit cabai no isolat 2

Hasil pengujian menunjukkan terjadi penghambatan sebesar $78,6 \%$. Mekanisme berupa antibiosis dan lisis yang ditunjukkan dengan terjadinya pembengkakan pada hifa, pemuntiran, dan lisis hifa yang berhadapan dengan bakteri endofit cabai. Penekanan penyakit antraknosa pada cabai juga telah dilakukan dengan aplikasi bakteri $B$. cereus.
Konsorsium tiga $B$. cereus dapat menekan penyakit antraknosa cabai sampai dengan intensitas penyakit 5\% (Yanti et al., 2020). Pengujian pengendalian penyakit in planta terhadap Colletotrichum sp. dilakukan dengan bakteri endofit dan tanpa bakteri ditunjukkan pada Tabel 4.

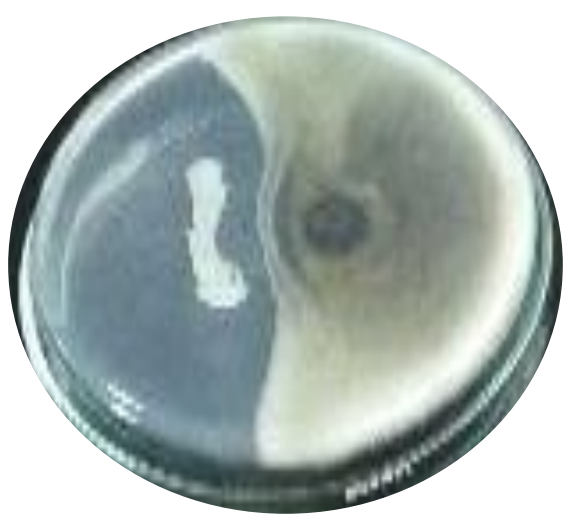

a

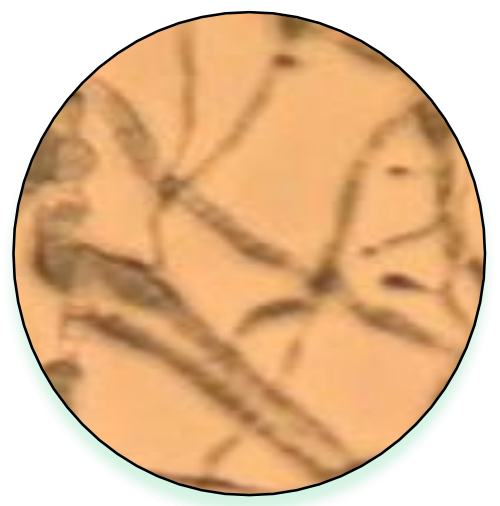

b

Gambar 2. Penghambatan pertumbuhan C. gloeosporioides oleh bakteri endofit cabai.(a).Penghambatan, (b) mekanisme penghambatan dengan pembengkakan hifa

Bakteri endofit seperti Bacillus subtilis mampu mengendalikan pertumbuhan Colletotrichum sp. karena diketahui mampu menghasilkan enzim kitinase. Enzim ini menunjukkan potensi bakteri tersebut sebagai pendegradasi dinding sel jamur yang 
komponen dinding selnya terdiri atas kitin. B.subtilis B298 menghasilkan kitinase dengan aktivitas sebesar $5,764 \mathrm{U} \mathrm{ml}^{-1}$ pada suhu inkubasi $40^{\circ} \mathrm{C}$, dan dengan waktu inkubasi 15 jam menunjukkan aktivitas 6,937 $\mathrm{U} \mathrm{ml}^{-1}$ (Lestari et al., 2017).

Hasil ini menunjukkan lebih cepat dibandingkan dengan Bacillus sp. HSA,3-1a menghasilkan kitinase dengan aktivitas $1,7 \mathrm{U}$ $\mathrm{ml}^{-1}$ pada inkubasi optimum $72 \mathrm{jam}, \mathrm{pH} 7$ dan konsentrasi substrat 0,3\% (Natsir et al., 2010).

Hasil penelitian menunjukkan bahwa aplikasi bakteri endofit pada buah cabai dapat menekan penyakit antraknosa dengan efektivitas 30,93\%. Penelitian sebelumnya (Prihatiningsih et al., 2019) perlakuan B. subtilis B298 formula mikroenkapsulan dapat menekan penyakit antraknosa di lahan dengan efektivitas sebesar $48 \%$. Pada buah cabai yang diperlakukan terlebih dahulu dengan bakteri endofit dapat menekan perkembangan penyakit antraknosa dengan efektivitas sebesar 30,93\%. Hal ini menunjukkan bahwa perlakuan bakteri endofit cabai maupun B. subtilis B298 merupakan salah satu cara untuk menekan komponen epidemi yaitu laju infeksi penyakit. Pengelolaan penyakit antraknosa selain dengan agens hayati adalah dengan teknik budidaya, varietas tahan, dan pengendalian kimiawi sebagai alternatif terakhir (Than et al., 2008; Narasimhan \& Shivakumar, 2015).

Tabel 4 Penekanan penyakit antraknosa pada buah cabai dengan bakteri endofit cabai

\begin{tabular}{lll}
\hline Perlakuan & $\begin{array}{l}\text { Luas } \\
\text { Serangan } \\
\left(\mathrm{mm}^{2}\right)\end{array}$ & $\begin{array}{l}\text { Efektivitas } \\
\text { penekanan } \\
(\%)\end{array}$ \\
\hline BE cabai & 67 & 30,93 \\
Tanpa & 97 & - \\
Bakteri & & \\
\hline
\end{tabular}

\section{SIMPULAN}

1. Penyakit antraknosa pada cabai di kecamatan Baturraden disebabkan oleh C. gloeosporioides yang teridentifikasi dari bentuk konidium lonjong lurus dan koloni putih dan bagian bawah hitam.

2. Intensitas penyakit tertinggi di desa Kemutug Lor sebesar $76 \%$, dan laju infeksi 0,345 unit hari ${ }^{-1}$. Faktor yang mempengaruhi perkembangan penyakit antraknosa di Kecamatan Baturraden adalah suhu udara dan kelembapan.

3. Pertumbuan $C$. gloeosporioides terbaik pada suhu $29^{\circ} \mathrm{C}$ dengan kecepatan pertumbuhan $14,72 \mathrm{~mm}$ hari $^{-1}$.

4. Penekanan penyakit antraknosa dapat dilakukan dengan bakteri endofit cabai dengan efektivitas 30,93\%. Bakteri endofit cabai selanjutnya dapat diformulasikan sebagai biopestisida yang efektif untuk pengendalian penyakit antraknosa.

\section{UCAPAN TERIMAKASIH}

Terima kasih disampaikan kepada DRPM Kemenristekdikti atas dana yang diberikan dalam penelitian penunjang kegiatan penelitian Stranas tahun 2017-2018. Kepada LPPM Unsoed diucapkan terima kasih atas fasilitas dan sarana guna mendukung penelitian ini.

\section{DAFTAR PUSTAKA}

Damm,U.,Woudenberg, JHC, C. \& Information, A. (2009). Colletotrichum species with curved conidia from herbaceous hosts. Fungal Diversity, (1802), pp. 45-87.

Herwidyarti KH, Ratih. S. \& Sembodo. DRJ. (2013). Keparahan penyakit antraknosa pada cabai. J. Agrotek 
Tropika, 1(1), pp. 102-106.

Jayawardana H.A.R.K, Weerahewa, H. L. D. \& Saparamadu M.D.J.S. (2015). Enhanced resistance to anthracnose disease in chili pepper (Capsicum annuum L) by amendment of the nutrient solution with silicon. Journal of Horticultural Science \& Biotechnology, 90(5), pp. 557-562.

Kommula SK, R. G. \& Undrajavarapu P, K. K. (2017). Effect of Various Factors (Temperature , $\mathrm{pH}$ and Light Intensity) on Growth of Colletotrichum capsici Isolated from Infected Chilli. Int.J.Pure App. Biosci., 5(6), pp. 535-543.

Lestari P, Prihatiningsih N, Djatmiko, H.A. (2017). Partial biochemical characterization of crude extract extracellular chitinase enzyme from Bacillus subtilis B 298. IOPscience.iop.org, 012041. doi: 10.1088/1742-6596/755/1/011001.

Machenahalli, S., Nargund, V. B. \& Patil, S. (2014). Quick Detection and Diagnosis of Chilli Fruit Rot Pathogens. International Journal of Plant Research, 27(3), pp. 1-5. doi: 10.5958/2229-4473.2014.00087.1.

Mishra, A., Ratan, V. \& Trivedi, S. (2018). Survey of anthracnose and wilt of chilli : A potential threat to chilli crop in central Uttar Pradesh. Journal of Pharmacognoct and Phytochemistry, 7(2), pp. 1970-1976.

Narasimhan, A. \& Shivakumar, S. (2015). Evaluation of Bacillus subtilis ( JN032305) biofungicide to control chilli anthracnose in pot controlled conditions. Biocontrol Science and Technology, 25(5), pp. 543-559. doi: 10.1080/09583157.2014.996737.

Natsir, H. Patong A.R., Suhartono, M.T., \& Ahmad A. (2010). Production and characterization of chitinase enzymes from sululu hot spring in south Sulawesi Bacillus sp. HSA , 3-1a. Indo.J.Chem., 10(2), pp. 263-267.

Oo, M. M. \& Oh, S. (2016). Chilli anthracnose (Colletotrichum spp) disease and its management approach. Korean Journal of Agricultural Science, 43 (2)(June), pp. 153-162. doi: 10.7744/kjoas.20160018.

van der Plank, J. E. (1963) Plant Disease: Epidemic and Control. Academic Press New York.

Prasad, R. R. (2016). Survey of Chilli Anthracnose; Potential Threat to Chilli Crop a Focus on Bulileka, Labasa, Fiji Island. International Journal of Scientific and Research Publications, 6(11), pp. 558-563.

Prihatiningsih, N., Djatmiko, Heru Adi, Erminawati. \& Lestari, P. (2019). Bacillus subtilis from Potato Rhizosphere as Biological Control Agent. 23(2), pp. 179-184. doi: 10.22146/jpti.40606.

Sangdee, A., Sachan, S. \& Khankhum, S. (2011). Morphological, pathological and molecular variability of Colletotrichum capsici causing anthracnose of chilli in the North-east of Thailand. African Journal of Microbiology Research, 5(25), pp. 4368-4372.doi:10.5897/AJMR11.476.

Saxena A, Raghuwanshi R, Gupta. V. K \& Singh. H.B. (2016). Chilli Anthracnose : The Epidemiology and Management Chilli Anthracnose : The Epidemiology and Management. Frontiers in Microbiology, 7, pp. 1-18. doi: 10.3389/fmicb.2016.01527.

Than, P. P., Prihastuti, H. \& Phoulivong, S. (2008). Chilli anthracnose disease caused by Colletotrichum species. 
Journal of Zheijiang University SCIENCE B, 9(10), pp. 764-778. doi: 10.1631/jzus.B0860007.

Welideniya, W. A. Rienzie K.D.R.C., Wickramaarachchi W.A.R.T, \& Aruggoda A.G.B. (2019). Characterization of fungal pathogens causing anthracnose in capsicum pepper (Capsicum annuum L .) and their seed borne nature. Ceylon Journal of Scence, 48(3), pp. 261-269.

Wulansari N K, Prihatiningsih. N. \& Djatmiko. H. A. (2017) 'Mekanisme antagonis lima isolat Bacillus subtilis terhadap Colletotrichum capsici dan C. gloeospoiroides in vitro. Agrin, 21(2), pp. 127-139.

Yanti, Y., Hamid, H. \& Habazar, T. (2020). The ability of indigenous Bacillus spp. consortia to control the anthracnose disease (Colletrotricum capsici) and increase the growth of chili plants. Biodiversitas, 21 (1)(January), pp. 179-186.doi:

10.13057/biodiv/d210123. 